$\mathbf{I}_{\text {nstitute of }} \mathbf{F}_{\text {ood }}$ and $\mathbf{A}_{\text {gricultural }} \mathbf{S}_{\text {ciences }}$

\title{
Macronutrient Deficiencies in Citrus: Calcium, Magnesium, and Sulfur ${ }^{1}$
}

\section{Mongi Zekri and Thomas A. Obreza ${ }^{2}$}

Perhaps the most distinctive observation about citrus nutrition is the variety of nutrient deficiencies that can appear under intensive cultivation. Visual deficiency symptoms of N, P, K, Ca, Mg, Fe, Zn, Mn, $\mathrm{B}, \mathrm{Cu}$, and Mo have been recognized both in the field and in artificial growing media. Nutrient deficiencies can usually be recognized by distinctive symptoms that most often occur in the leaves, but can sometimes be seen in the fruit, branches, or general growth of the tree. In some cases, a combination of deficiencies, excesses, or both may mask typical symptoms of a single element and make positive visual identification more difficult. In such cases, leaf analysis can provide a more accurate identification. The degree of deficiency may be measured by the severity of the symptoms and the number of growth terminals affected. Citrus growers should be able to recognize deficiency symptoms, know the treatment necessary to correct them, and be cautious about confusing deficiency symptoms with conditions resulting from diseases, insects, nematodes, flooding, or other causes.

The use of specific symptoms as guides to the nutritional needs of citrus trees has been common for many years. The symptoms of $\mathrm{N}, \mathrm{Mg}, \mathrm{Fe}, \mathrm{Zn}, \mathrm{Mn}$, and $\mathrm{Cu}$ deficiency are quite definite and easily recognizable. This information has been of great value as a guide to the nutritional needs of the tree. Mineral deficiency has been much more widely observed in Florida than other citrus-growing areas because of the sandy, low organic matter soils, heavy leaching rains, and large crops that remove substantial amounts of nutrients.

\section{Calcium (Ca)}

A deficiency of calcium in citrus is expressed as a fading of the chlorophyll along the leaf margins and between the main veins during the winter months. Small necrotic (dead) spots can develop in the faded areas. Calcium deficiency produces small, thickened leaves and causes loss of vigor, thinning of foliage and decreased fruit production. Severely deficient trees can develop twig dieback and multiple bud growth of new leaves. Trees grown under $\mathrm{Ca}$ deficiency produce undersized and misshapen fruit with shriveled juice vesicles. Fruit from Ca-deficient trees are slightly lower in juice content but higher in soluble solids and acids.

Calcium deficiency usually occurs on acidic soils where native $\mathrm{Ca}$ has leached. Continuous use of ammonium-containing fertilizer, particularly

1. This document is SL 202, a fact sheet of the Soil and Water Science Department, Florida Cooperative Extension Service, Institute of Food and Agricultural Sciences, University of Florida. First printed: January 2003. Please visit the EDIS Web site at http://edis.ifas.ufl.edu.

2. Mongi Zekri, Multi-County Citrus Agent, Hendry County Extension Office and Thomas A. Obreza, Professor, Soil and Water Science Department, Florida Cooperative Extension Service, Institute of Food and Agricultural Sciences, University of Florida, Gainesville, 32611-0290. 
ammonium sulfate, accelerates Ca loss from soils. Use of muriate of potash and sulfur cause similar losses of soil Ca. Liming the soil not only neutralizes soil acidity but also supplies available $\mathrm{Ca}$. Calcium deficiency can also occur in highly saline soils due to the excessive sodium ( $\mathrm{Na}$ ) concentration. Under such a situation, gypsum can correct the deficiency and reduce the deleterious effect of $\mathrm{Na}$. Calcium deficiency can also be corrected by foliar spraying with a water-soluble $\mathrm{Ca}$ source.

\section{Magnesium (Mg)}

Magnesium deficiency has been a major worldwide problem in citrus production. In Florida, $\mathrm{Mg}$ deficiency is commonly referred to as "bronzing". Trees with inadequate Mg supply may have no symptoms in the spring growth flush, but leaf symptoms will develop as the leaves age and the fruit expand and mature in the summer and fall. Magnesium deficiency symptoms occur on mature leaves following the removal of $\mathrm{Mg}$ to satisfy fruit requirements. During the summer, when a rapid increase in fruit size occurs, the symptoms appear on leaves close to the developing fruit. Magnesium deficiency symptoms appear as a result of translocation of $\mathrm{Mg}$ from the leaves to the developing fruit, although there may also be a translocation from older leaves to young developing leaves on the same shoot.

Disconnected yellow areas or irregular yellow blotches start near the base along the midribs of mature leaves that are close to fruit. They become gradually larger and eventually coalesce to form a large area of yellow tissue on each side of the midrib. This yellow area enlarges until only the tip and the base of the leaf are green, showing an inverted $\mathrm{V}$-shaped area pointed on the midrib. In acute deficiency, the yellow area may gradually enlarge until the entire leaf becomes yellow or bronze in color.

Leaves that have lost most of their green color drop freely under unfavorable conditions such as cold weather, water stress, or heavy foliar sprays. Defoliated twigs are weak and usually die by the following spring, necessitating pruning of trees. There are neither primary twig symptoms nor striking fruit symptoms associated with $\mathrm{Mg}$ deficiency, but a secondary effect following defoliation may lead to the death of many twigs. Severe defoliation will reduce the average size of individual fruit and cause a general decline in fruit production.

The mobility of $\mathrm{Mg}$ in the tree differentiates it from $\mathrm{Fe}, \mathrm{Zn}, \mathrm{Mn}$, and $\mathrm{Cu}$. The symptoms due to deficiencies of these micronutrients develop on new growth, while $\mathrm{Mg}$ deficiency occurs only on mature leaves that were previously normal in appearance and usually on limbs bearing a heavy crop. Heavily fruited limbs develop extreme Mg deficiency symptoms and may even become completely defoliated, while limbs with little or no fruit may not show deficiency symptoms.

Cultivars producing seedy fruit are more severely affected by $\mathrm{Mg}$ shortage than cultivars producing seedless fruit. Alternate bearing is common in seedy cultivars growing under $\mathrm{Mg}$-deficient conditions. The loss of wood as a result of defoliation reduces the fruit-bearing wood for the following year. Magnesium deficiency can result in a great reduction not only in fruit yield but also in fruit quality. Fruit from $\mathrm{Mg}$-deficient trees are lower in soluble solids, acidity, and vitamin C. Magnesium deficiency makes trees more susceptible to cold injury than non-deficient trees.

In Florida, $\mathrm{Mg}$ deficiency is caused primarily by low soil $\mathrm{Mg}$ concentration. It is particularly severe on acidic sandy soils, from which $\mathrm{Mg}$ readily leaches. Leaching of added $\mathrm{Mg}$ is particularly serious and substantially rapid when the soil $\mathrm{pH}$ is 4.5 to 5.0. Under such conditions, the use of dolomite to raise the $\mathrm{pH}$ above 6.0 will furnish $\mathrm{Mg}$ at the same time. Soil application of $\mathrm{Mg}$ sulfate or oxide can be successful in correcting Mg deficiency when the soil $\mathrm{pH}$ is adjusted. Salinity, fertilizers high in potassium salts, and manures have been shown to induce or aggravate $\mathrm{Mg}$ deficiency. Magnesium deficiency can also be attributed to calcareous soils relatively low in $\mathrm{Mg}$ or to unbalanced conditions in the soil due to excessive $\mathrm{K}$ or $\mathrm{Ca}$. Under these conditions, the amount of $\mathrm{Mg}$ applied must be greater than that applied on soils lower in $\mathrm{Ca}$ or $\mathrm{K}$. 
In Florida, one foliar spray application of $\mathrm{Mg}$ is not always effective in correcting the deficiency when the amount of $\mathrm{Mg}$ needed is greater than the amount that can be absorbed by the leaves. Foliar sprays of $\mathrm{Mg}$ nitrate can be effective when applied to the spring flush leaves when they are two-thirds to fully expanded but not hardened off. Leaves that have already developed the deficiency pattern will not completely recover when $\mathrm{Mg}$ is applied, but deficiency symptoms can be prevented the following season.

\section{Sulfur (S)}

Since $\mathrm{S}$ is associated with the formation of proteins and chlorophyll, deficiency symptoms resemble those of $\mathrm{N}$, but they first appear on the new growth. Plants are stunted and pale green to yellow in color. Such chlorosis in citrus is worse on new growth because $\mathrm{S}$ does not move readily from old to young leaves like N. Sulfur deficiency occurs most commonly with high $\mathrm{N}$ fertilizer rates. If the supply of $\mathrm{N}$ is not supplemented with adequate $\mathrm{S}$, the $\mathrm{N}$ available for crop use may be excessive in relation to $\mathrm{S}$. Under high $\mathrm{N}$ and low $\mathrm{S}$ conditions, plant growth processes are disrupted and plants develop symptoms of S deficiency. Sometimes, total growth is reduced by fertilization with $\mathrm{N}$ alone, whereas combined applications of $\mathrm{N}$ and $\mathrm{S}$ have provided normal growth and yield.

In the past, many traditional citrus fertilizers like ordinary superphosphate contained $\mathrm{S}$ as part of the mixture. In addition, elemental $\mathrm{S}$ was often used as a summer miticide. However, the use of fertilizers that are essentially S-free like ammonium nitrate, potassium nitrate, urea, and concentrated superphosphate have become increasingly popular. The use of these fertilizers can indirectly induce $S$ deficiency. Sulfur deficiency in citrus can easily be corrected by soil application of S-containing fertilizers like ammonium sulfate, potassium sulfate, or magnesium sulfate. Applying gypsum is an inexpensive option that can also correct $\mathrm{S}$ deficiency. 